\title{
Combining different methods of data collection in public service interpreting doctoral research: examples from the Spanish context
}

\author{
Mireia Vargas-Urpi \\ Universitat Pompeu Fabra, Spain \\ mireia.vargas@upf.edu
}

DOI: 10.12807/ti.109201.2017.a07

\begin{abstract}
During the past ten years, public service interpreting (PSI) has become a flourishing field of research. Different kinds of studies have explored issues such as the role of public service interpreters, accuracy and deviations in their renditions, or primary participants' views on and expectations of PSI. In terms of research methods, it is becoming increasingly popular to combine different data collection methods in the field of PSI, especially in large research projects. The aim of this article is to describe how multiple datasets have been used in a sample of studies. It presents a review of $\mathrm{PhD}$ dissertations in Spain that have combined different kinds of surveys, focus groups and/or direct observation. This is followed by a description of how a multimethod approach can contribute to the advance of PSI research and how it can compensate for the limitations of certain single-method approaches to PSI. It argues that, while multimethod research may be more demanding and time-consuming from the researcher's point of view, it is more effective in terms of providing a holistic view of the object of study.
\end{abstract}

Keywords: public service interpreting, community interpreting, qualitative research, $\mathrm{PhD}$ dissertations, triangulation, multimethod approach

\section{Introduction}

Research into public service interpreting (PSI), also known as community interpreting, has multiplied and diversified over the past ten years. Different kinds of studies have explored issues such as the role of public service interpreters, accuracy and deviations in their renditions, or primary participants' views and expectations of PSI, to name but just a few. As Hale (2007) observes, certain approaches stand out: discourse analysis of the transcriptions of interpreted interactions, ethnography, survey research and experimental approaches (p.204). While PSI is consolidating itself as a field of research within the broader discipline of Translation and Interpreting Studies, it is also at the stage where we can see an increase in the use of multimethod studies, perhaps as a result of increased research funding in the field and the availability of a critical mass of trained researchers.

Combining various data collection methods is becoming popular in the field of PSI, especially in extended research projects such as internationally funded projects or $\mathrm{PhD}$ dissertations. This article presents a review of $\mathrm{PhD}$ dissertations conducted in Spanish institutions that have relied on multiple 
data collection tools, combining different kinds of surveys, focus groups and/or direct observation. This could be regarded as a multimethod approach to PSI. The label 'multimethod approach' refers to research that employs more than one method of data collection or research in a study. Hale and Napier (2013) suggest that 'multimethod research' is a synonym for 'mixed methods' (p.210). However, 'mixed methods' seems to be more related to the mix of qualitative and quantitative paradigms (in both data collection and analysis), while the 'multimethod' approach may fall under one of these paradigms (typically the qualitative), and simply imply the use of different methods of data collection and analysis under that specific paradigm.

According to Brewer \& Hunter (2006), "[i]ts fundamental strategy is to attack a research problem with an arsenal of methods that have nonoverlapping weaknesses in addition to their complementary strengths." (p. 4). That is, the purpose of using more than one method is to compensate for the possible limitations resulting from adopting only one particular method. For the purpose of this article, the term 'multimethod approach' is used to refer mainly to the combination of different data collection methods in one specific study, although its actual meaning is broader and includes analytical methods.

As Brewer and Hunter (2006) point out, applying different methods often requires some kind of 'triangulation' (or triangulated measurement in the authors' words): a strategy which "tries to pinpoint the values of a phenomenon more accurately by sighting in on it from different methodological viewpoints" (pp. 4-5). Campbell \& Fiske (1959) were the first to introduce triangulation in a paper addressing quantitative research (as cited in Drisko, 2015). However, it was Denzin $(1970,1978)$ who introduced "a much more generally applicable, multidimensional conceptualization of triangulation" (as cited in Drisko, 2015), thus expanding the scope and possibilities of triangulation. Denzin's (1978) classification of the four basic types of triangulation has attracted particular scholarly attention:

- data triangulation, in which different data sources are examined using the same method (for example, data collected at different points in time; or interviewing different groups on the same topic) in order to confirm findings or compensate for weaknesses;

- investigator triangulation, in which more than one researcher analyses the same data in a study to confirm findings;

- theory triangulation, in which multiple theories or hypotheses are used to examine a situation or phenomenon (i.e. using divergent theories to identify different issues or concerns);

- methods triangulation, in which various data collection methods are used to check the consistency of findings (i.e. using multiple methods to study a situation or phenomenon).

Nevertheless, the term 'triangulation' has also been the object of certain criticism. For instance, Hammersley (2008) explains that one of the problems with 'triangulation' is that it has been attributed at least four different meanings:

- Triangulation as validity checking, i.e. triangulation is used as a way of "checking the validity of an interpretation based on a single source of data by recourse to at least one further source that is of a strategically different type" (Bergman, 2008, p.23). Very often, researchers report having drawn data from different sources or using different methods of analysis to "reduce the chances of reaching false conclusions" (ibid.).

- Indefinite triangulation. This term was coined by Cicourel (1974), 
who designed 'indefinite triangulation' to "make visible the practicality and inherent reflexivity of everyday accounts". According to Seale (2003), 'indefinite triangulation' suggests that "every reading of a text is likely to produce a new interpretation, with no version assuming privileged status" (p.179).

- Triangulation as seeking complementary information. As Hammersley (2008) suggests, this is the most common meaning: researchers talk about triangulation when they use different methods to investigate a specific reality; however, even though these different perspectives "might not be useful to validate each other (...) [they] might yield a fuller and more complete picture of the phenomenon concerned if brought together" (Erzberger \& Kelle, 2003, as cited in Hammersley, 2008, p.27).

- Triangulation as epistemological dialogue or juxtaposition. According to Flick (1998), the focus of triangulation "has shifted increasingly toward further enriching and completing knowledge and towards transgressing the (always limited) epistemological potentials of the individual method" (p.230). Or, as Hammersley (2008) explains, "different methods construct the social world in divergent ways, so that combining them may not lead to either validation or to increasing the completeness of the picture" (p.28).

What emerges as the common denominator is that different data collection tools are employed and that, very often, different datasets are analysed independently, yielding different sets of results. Researchers may then use this duplicated (or triplicated) information on the same phenomenon either to cross-check each set of results (which would entail some kind of validation), to compare different interpretations of the same reality, to draw a broader picture of what they are examining (i.e. the results from one dataset are used to complement the results of other datasets) or to juxtapose diverging epistemological positions.

Section two reviews and discusses various studies which have used multiple data collection methods in PSI, while section three contextualises the work reported in section two vis-à-vis a brief overview of PSI doctoral research across Europe.

\section{Multiple data collection methods in PSI doctoral research in Spain}

PSI has produced many different research themes over recent years (VargasUrpi, 2012a). Many of the studies developed in the field have tried to provide a holistic - while also detailed - view of this emerging profession in certain settings or countries. Furthermore, PSI is interdisciplinary in essence: it is a complex activity that requires explanations which can only be provided by different disciplines. This may well explain why various disciplines (e.g. interpreting studies, applied linguistics, sociology, psychology, anthropology or communication sciences) have complemented each other in PSI research (Vargas-Urpi, 2011). This has fostered the trend towards the multimethod approaches described in this article, which have been particularly noticeable in large research projects as well as in $\mathrm{PhD}$ dissertations, where researchers usually have more space and time to collect data from different sources and build different datasets.

This section reviews various studies that have used multiple data collection tools. It focuses on $16 \mathrm{PhD}$ dissertations defended over the past 10 
years (2006-2015) in Spain. A significant number of theses on interpreting have been defended in Spain in recent years, partially due to the pressure on faculty members to have PhDs in order to obtain tenure (Xu, 2015, p.34). This is of course a small sample that does not account for the research in PSI worldwide, but the purpose here is to illustrate how multiple data collection methods have been developed in the frame of $\mathrm{PhD}$ dissertations in the specific case of Spain. The choice of the Spanish context has been motivated by the author's facilitated access to this body of dissertations (not only the abstracts).

The first source used to identify dissertations on PSI in Spain was BITRA: Bibliography of Interpreting and Translation (Franco Aixelá, 20012016). BITRA, developed at the University of Alicante, is one of the world's largest bibliographic repositories of Translation and Interpreting Studies, with over 68,000 entries at the time of writing this article. On $10^{\text {th }}$ March 2017, a search in BITRA using the keywords 'Interpreting' + 'Community' while adding the type of document ("dissertation") and the time span selected (20062015 ) produced 15 results, of which only 6 were defended in Spain. As new references are constantly being incorporated into BITRA, future searches may produce slightly different results.

This small number is due to some dissertations not being labelled as 'community' but as 'legal' or 'medicine', while others have only been labelled as 'interpreting', such as Davitti's (2012) thesis on dialogue interpreting. For this reason, a second search was performed using only 'interpreting' as the keyword, "dissertation" as the type of document, and the time span selected. This second search rendered 116 matches, which were revised one by one by the author. From these, 26 concerned PSI, ${ }^{i}$ among which 10 had been defended in a Spanish university.

This list was then completed with references from an unpublished catalogue of PhD dissertations, MA theses and undergraduate theses on PSI in Spain, which is being developed by the Comunica network and currently under construction. ${ }^{\text {ii }}$ From this catalogue, a total of 6 dissertations were added, making up a sample of 16 theses devoted to PSI for the period of 2006-2015 (see Annex 1). This sample is not exhaustive of the period 2006-2015, because there may be theses that do not appear in either of these catalogues. These dissertations have been reviewed taking into consideration three major aspects: (a) the data collection procedures used; (b) whether the theses explicitly mention the application of any kind of triangulation; (c) their length in pages (see Annex 1 for more detailed information).

Of the sample of 16 dissertations, 12 combined different kinds of data collection tools $(75 \%)$. Four of these explicitly mention that they relied on an ethnographic approach (Baixauli Olmos, 2012; Nevado Llopis, 2013; Onos, 2014; Vargas-Urpi, 2012b). Nevado Llopis (2013) quotes Guber's (2001) definition of 'ethnography', where the term is understood as both the "conception and practice of knowledge that seeks to understand social phenomena from the perspective of its members (members being understood as 'actors', 'agents' or 'social subjects". iii If we consider PSI a social phenomenon that involves members from various groups (interpreters, users, public service providers, coordinators and managers of PSI services, and policy-makers), the use of different data collection methods may facilitate access to all their perspectives. This also stresses the interdisciplinary nature of PSI. Perhaps the most representative of these studies is that of Nevado Llopis (2013) on healthcare interpreting, which describes four different data collection methods under the approach of ethnography:

- Collection of documents related to immigrants' rights, patients' access and use of healthcare services, reproductive health, etc. for document analysis; 
- 49 semi-structured in-depth interviews with healthcare providers and migrant users;

- Non-participant observation of 14 medical consultations;

- 3 focus groups.

It may be worth mentioning that the focus groups pursued the confirmation of the data collected through the other three methods, especially in the case of ambiguous results. Nevado Llopis mentions the application of different kinds of triangulation (data triangulation, theoretical triangulation and methodological triangulation) to ensure accuracy and bring breadth and depth to the study.

Baixauli-Olmos (2012) pursued a similar approach, even though his object of study is substantially different: a critical review of deontological codes from the point of view of their (potential) application to interpreting in prisons. More specifically, his data collection involved:

- Collection of deontological codes for document analysis;

- 5 semi-structured interviews with prison managers (2) and public service interpreters (3);

- 72 semi-structured questionnaires with prison managers (6), workers (10), inmates (9) and public service interpreters (47);

- Direct observation through visits to a prison and through the organisation of a workshop for inmates.

Baixauli-Olmos (2012) explains that his first intention was to become a public service interpreter for a prison, a first-hand experience that would give him a privileged glimpse of the field of practice (p.178). However, due to security restrictions, he was not granted the necessary authorisation and had to change his strategy, which is the reason he resorted to visits and a workshop for inmates who had some experience in interpreting for other inmates. BaixauliOlmos (2012) also mentions having used a multiple-triangulation approach (data triangulation, theoretical triangulation and methodological triangulation), quoting Denzin (1989), in order to merge the data obtained from different sources that were then analysed according to different theories and using different methods (p.164). He also describes his own research as "intermethodological" and "transdiciplinary".

Nevado Llopis' (2013) and Baixauli-Olmos' (2012) are the two dissertations that have employed the most significant combinations of data collection techniques. This may also be a consequence of sharing the same supervisors (Dr. Raga Gimeno and Dr. Sales Salvador) at Jaume I University.

What is also frequent is the combination of just two or three data collection tools, and, particularly, the use of questionnaires or interviews complemented with direct observation. For instance, Onos (2014), in a dissertation about Romanian interpreting in courts in Barcelona, used 14 semistructured interviews with some of the actors involved in court interpreting (5 interpreters, 4 judges and 5 lawyers) and observation of 56 court sessions (trials or proceedings) where interpreting for Romanian defendants was required; while Bodzer (2014), researching PSI for gender violence victims, relied on extensive fieldwork by means of questionnaires and brief interviews with interpreters, lawyers, psychologists, social workers, victims and managers of emergency centres and shelter houses; ${ }^{\text {iv }}$ and observation of 37 trials involving gender violence in Madrid. Isac (2008) also used questionnaires and direct observation, but in her case it was clearly 'participant observation' because her position as a practitioner gave her easy access to the field. Martínez-Gómez (2011) had a more focused objective evaluating the quality of natural interpreters in prison settings - and used the following combination of data collection instruments: 
- She distributed two questionnaires to the direct users of interpretation in a prison setting, i.e. inmates and prison officers. The first questionnaire was completed before an interpreted meeting and it contained questions about users' expectations of interpreting; the second questionnaire was answered after the interpreted meeting and it collected users' evaluations of the interpretation received.

- She also collected basic information about the interpreters using a questionnaire.

- She recorded 19 interpreted meetings in order to determine their quality by means of an evaluation matrix.

Other theses have synthesised compilations of documents (for document analysis) with questionnaires or interviews. This is the case of Wallace (2012), who collected 84 questionnaires and then analysed nearly 6,000 raw certification exam scores in the Spanish-English language pair. ${ }^{v}$ Ortega Herráez (2006) devotes the first part of his dissertation to the description of the situation of court interpreting in Spain, mainly by examining legislative and other kinds of documents, while in the second part, he analyses the 83 questionnaires he had given to court interpreters.

Both Vargas-Urpi (2012b) and Burdeus Domingo (2015) used interviews which were complemented with data collected by means of questionnaires. In both cases, the interviews and questionnaires were grouped according to the informants' roles (e.g. interpreters, managers and stakeholders, users, etc., see Annex 1 for more detailed information about the number of interviews conducted). This resulted in different datasets that could be analysed independently and then triangulated in a final stage.

The triangulation used as a strategy to compare and complement the data extracted from the analyses of different datasets is a common feature in the dissertations by Vargas-Urpi (2012b), Onos (2014) and Burdeus Domingo (2015). In fact, both Vargas-Urpi and Onos use triangulation to discuss their findings and to introduce the conclusions of their research. Burdeus Domingo (2015) used interviews to elicit data from various samples of informants (interpreters and mediators, coordinators of interpreting and mediation services, and doctors) and questionnaires to collect users' views. The same multiple data collection methods were also conducted in two cities: Barcelona and Montreal. Thus, her dissertation includes three triangulations: one for the results of the data collected in Montreal; one for the results of the data collected in Barcelona; and finally, one for the comparison of each city's results.

Another interesting aspect about the PSI doctoral theses reviewed is their average length: 594 pages. In fact, seven of the dissertations exceed 600 pages: Baixauli-Olmos (2012), Bodzer (2014), Burdeus Domingo (2015), Martínez-Gómez (2011), Nevado Llopis (2013), Ortega Herráez (2006) and Vargas-Urpi (2012b), and this may also be related to the use of multiple data collection strategies (and, consequently, multiple data analysis methods according to each type of data).

Finally, although not a dissertation, it is also worth mentioning the SOSVICS project, led by the University of Vigo, which is another illustrative example of the multimethod approach in PSI. The SOS-VICS project had the objective of describing communication between non-Spanish speaking victims of gender violence and the public service providers involved in their assistance (police, judges, lawyers, social workers, psychologists, interpreters, etc.). This information was then used to prepare training material and resources for interpreters as well as recommendations for public service providers. The use of a truly multimethod data collection strategy was especially useful for the 
broad objective of describing communication in the wide range of contexts and situations that gender violence involves:

- Questionnaires were distributed to public service providers (Del Pozo Triviño et al., 2014a);

- A questionnaire using the Delphi approach $^{\mathrm{vi}}$ was distributed to interpreters with experience interpreting for victims of gender violence (Del Pozo Triviño et al., 2014b);

- In-depth interviews were conducted with non-Spanish speaking victims of gender violence and with expert informants (e.g. emergency centre managers, coordinators of projects focussed on gender violence, or psychologists specialised in gender violence, among others);

- Workshops with public service providers were organised to promote brainstorming on the issues that should be included in the materials produced as a result of the project.

The data collection was extensive and each dataset produced wide-ranging results, which clearly provided a panoramic view of the object of study, while also considering the perspectives of all the actors involved. No specific triangulation strategy was employed in this study to merge the results extracted from each dataset, so while it presents a specific reality from a holistic perspective, it only does so from a detailed description of the different elements that compose it. It is true that some of the questions posed to interpreters (e.g. "what contents would you like to find in a specialised training course for interpreting for gender violence victims?") were not triangulable with responses from the other datasets, which may be one of the reasons why no overall triangulation was conducted.

\section{Doctoral research in Spain vis-à-vis its European counterparts}

In order to contextualise the work reported in the previous section, this section briefly provides general information about a sample of theses presented in the European context and retrieved through BITRA.

As already explained, a search using the keyword 'interpreting' and adding the type of document ("dissertation") and the time span selected (20062015) produced 116 matches. From these, 26 concerned PSI; 10 had been defended in Spain, 13 in other European countries and 3 in non-European countries (Australia, Japan and China). One may object to a potential bias in favour of including theses defended in Spain because BITRA is maintained and updated in this country, but a glimpse at the overall figures reveals its global scope: according to its latest report, published in November 2016, it includes 68,050 entries, of which 1,599 correspond to theses (Franco Aixelá, 2001-2016). Despite not being exhaustive, it is aleatory; therefore, the 13 theses retrieved by BITRA may be useful to contextualise the information presented in the previous section (see Annex 2 for more information).

Among the 13 theses on PSI presented in Europe and retrieved by means of BITRA, 4 have used various methods of data collection (Fowler, 2012; Hussein, 2011; Keselman, 2009; Krystallidou, 2013). The proportion is clearly smaller than in the Spanish case: while $75 \%$ of PSI doctoral research in Spain has used multiple data collection tools, only $31 \%$ has done so in this second sample of European (non-Spanish) theses.

Accordingly, triangulation is only mentioned by Fowler (2012), who justifies its use because it is "the methodological approach most likely to fulfil 
the conditions of reducing (but not eliminating) the possibility of ambiguity or bias in the interpretation of the data" (p.78). Fowler also acknowledges the criticism that triangulation has received.

On average, the European (non-Spanish) doctoral theses on PSI reviewed are also substantially shorter: 292 pages. The theses presented in Spain double the ones presented in other European countries in terms of average length.

\section{Conclusions}

This article has revisited some examples of research using multiple data collection methods in PSI. I have reviewed various dissertations that relied on the multimethod approach in terms of data collection methods. Most of these dissertations fall under the umbrella of the qualitative paradigm and had the objective of describing and analysing PSI in a broad sense. The diverse methods of data collection used in a qualitative study make it an appropriate approach for studying a phenomenon in greater depth, holistically, and from an interdisciplinary perspective.

Despite the obvious differences, all the studies reviewed in this article share some common ground: they all involved either questionnaires or interviews as part of their data collection methods. These are clearly the two most recurring data collection tools in PSI research — Pöchhacker (2004) also notes the predominance of surveys as a research method in PSI (p.63), while Hale \& Napier (2013) devote a whole chapter to questionnaires and various sections to interviews. They have proved useful for very different purposes: they help us understand PSI as a whole in a certain setting or area (e.g., Burdeus Domingo, 2015; or Onos, 2014, among others), or provide specific information about certain aspects (e.g., about certification exams, as in Wallace, 2012; or about nonverbal communication in PSI, as in Vargas-Urpi, 2013). Furthermore, when combined with other data collection methods, interviews (sometimes in the form of a focus group) can also be used as a control device to ensure the validity of data collection procedures (e.g. Hunt Gómez, 2012; Nevado Llopis, 2013).

The studies revisited seem to reflect a clear influence of ethnography, where multiple data collection strategies are also frequent. PSI is a profession that is relatively new in many countries, thus it may be natural that researchers look for inspiration from ethnographic approaches to collecting information to describe this new reality.

The article has also shown that another recurring term in the multimethod approach is triangulation. As we have seen in the studies reviewed, many of them explicitly state that they rely on triangulation to ensure validity and objectivity, but very often it is only used as a method for merging all the results of various analyses and presenting a broader picture of the phenomenon under study. In this regard, we may need to refine our definition of 'triangulation' and its purposes, as already suggested by Hammersley (2008).

All in all, multiple data collection methods are common in the research conducted in Spain, which has been the focus of this article. The sample of European non-Spanish theses was comparatively smaller, but it was aleatory and it still reveals that multiple data collection tools are more frequently used in Spain than in other European countries. Consequently, PSI theses in Spain rely more on triangulation and are substantially longer than their European counterparts. Further research is needed to confirm these differences and to find possible explanations for them. Very often, though, the use of various data collection methods is a 'forced' option when a single data collection 
method produces limited data (insufficient for research purposes), possibly due to external factors such as lack of authorisation or limited availability of informants.

Multiple data collection tools present certain disadvantages, which are, in fact, common to most kinds of empirical studies (in any discipline). First of all, collecting data in PSI often implies the unavoidable step of seeking approval to distribute questionnaires, to conduct interviews or to access certain settings for direct observation. This was a particular hurdle in the two dissertations dealing with interpreting in prisons in Spain (Baixauli-Olmos, 2012; Martínez-Gómez, 2011). This is also a reason relatively few empirical studies exist for PSI. The second hindrance is that it is usually quite challenging to make arrangements for PSI informants to participate in interviews, focus groups or direct observation. Data treatment prior to analysis is also time-consuming when various data collection tools have been conducted, and transcribing interviews or recordings of interactions is highly demanding. Finally, what could be regarded as a 'collateral' drawback of such diverse data collection tools is that it is then difficult to make them fit into the limitations of a journal article in order to publish the holistic findings of the research in a more condensed form.

The most significant advantage of multiple data collection tools is perhaps that they are very suitable for studies that seek to provide both detailed and holistic descriptions. Present figures seem to suggest that dissertations using the multimethod approach are currently a trend - at least in Spain. However, the development of research in PSI may also make such vast doctoral theses unnecessary. Instead, more focused interdisciplinary research may be more appropriate in future generations of theses.

\section{Acknowledgements}

This article is part of the project funded by the Spanish Ministry of Economy and Competitiveness (FFI2014-55029-R) "The quality in translation as an element to safeguard procedural guarantees in criminal proceedings: development of resources to help court interpreters" of the MIRAS research group (UAB).

The author would like to thank Roland Keith Pearson and Cole Axtell Morrison for proofreading the paper.

\section{References}

Abril Martí, M. I. (2006). La Interpretación en los Servicios Públicos: Caracterización como género, contextualización y modelos de formación. Hacia unas bases para el diseño curricular. (Doctoral thesis, Universidad de Granada, Granada, Spain). Retrieved from: https://hera.ugr.es/tesisugr/ 16235320.pdf

Baixauli-Olmos, L. (2012). La interpretació als serveis públics des d'una perspectiva ètica: la deontologia professional i l'aplicació al context penitenciari. (Doctoral thesis, Universidad Jaume I, Castelló de la Plana, Spain). Retrieved from: http://www.tdx.cat/handle/10803/83723

Bodzer, A. (2014). La interpretación en los servicios públicos desde la perspectiva de género. Aproximación al caso de la interpretación para mujeres no hispanohablantes víctimas de violencia de género. (Unpublished doctoral thesis, Universidad de Alcalá, Alcalá de Henares, Spain).

Brewer, J. \& Hunter, A. (2006). Foundations of multimethod research: synthesizing style. Thousand Oaks, CA: Sage. 
Burdeus Domingo, N. (2015). La interpretación en los servicios públicos en el ámbito sanitario. Estudio comparativo de las ciudades de Barcelona y Montreal. (Doctoral thesis, Universitat Autònoma de Barcelona, Cerdanyola del Vallès, Spain). Retrieved from: http://www.tdx.cat/handle/10803/310427

Campbell, D., \& Fiske D. (1959). Convergent and discriminant validation by the multitrait-multimethod matrix. Psychological Bulletin, 56.2 (March), 81-105. http://dx.doi.org/10.1037/h0046016

Cicourel, A. V. (1974). Cognitive sociology. Harmondsworth: Penguin.

Cohen, L.; Manion, L.; \& Morrison, K. (2011). Research methods in education ( $^{\text {th }}$ ed.). Abingdon, Oxon: Routledge.

Cuhls, K. (2005). The Delphi Method. In: K. Cuhls (ed.): Delphi surveys. Teaching material for UNIDO foresight seminars. (p. 93-112). Wien: UNIDO. Retrieved from: http://www.unido.org/fileadmin/import/16959_DelphiMethod.pdf

Del Pozo Triviño, M. I; Vaamonde Liste, A.; Casado-Neira, D.; Pérez Freire, S.; Vaamonde Paniagua, A.; Fernandes del Pozo, D. \& Guinarte Mencía, R. (2014a). Communication between professionals providing attention and gender violence victims/survivors who do not speak the language. A report on the survey carried out on agents during the Speak Out for Support (SOS-VICS) project. Universidad de Vigo. Retrieved from: http://cuautla.uvigo.es/sos-vics/blogs/files/informecuestionario-2015.pdf

Del Pozo Triviño, M. I; Vaamonde Liste, A.; Casado-Neira, D.; Pérez Freire, S.; Vaamonde Paniagua, A.; Fernandes del Pozo, D. \& Guinarte Mencía, R. (2014b). Specialised training for interpreters working with gender violence victims/survivors. A report on the Delphi survey carried out on interpreters during the Speak Out for Support (SOS-VICS) project. Universidad de Vigo. Retrieved from: http://cuautla.uvigo.es/sos-vics/blogs/files/informe-delphi-2015. pdf

Denzin, N. (1970). The research act: A theoretical introduction to sociological research methods. Chicago: Aldine.

Denzin, N. (1978). Sociological methods. New York: McGraw-Hill.

Drisko, J. (2015). Triangulation. Oxford bibliographies [online resource]. doi: 10.1093/OBO/9780195389678-0045

Erzberger, C. \& Kelle, U. (2003). Making inferences in mixed methods: the rules of integration. In A. Tashakkori \& C. Teddlie (eds.). Handbook of mixed methods in social and behavioral research. Thousand Oaks, CA: Sage.

Foulquié Rubio, A. I. (2015). Interpretación en el contexto educativo: la comunicación docentes-padres extranjeros. (Doctoral thesis, Universidad de Murcia, Murcia, Spain). Retrieved from: http://hdl.handle.net/10803/362090

Flick, U. (1998). An introduction to qualitative research. London: Sage.

Fowler, Y (2012). Non-English-speaking defendants in the magistrates court a comparative study of face-to-face and prison video link interpreter-mediated hearings in England. (Doctoral thesis, Aston University, Birmingham, United Kingdom). Retrieved from: http://publications.aston.ac.uk/19442/1/ Student thesis-2013.pdf

Franco Aixelá, J. (2001-2016). BITRA (Bibliography of Interpreting and Translation). Open-access database. Available at: http://dti.ua.es/en/bitra/ introduction.html doi: $10.14198 /$ bitra

Hammersley, M. (2008). Troubles with triangulation. In M. M. Bergman (ed.) Advances in mixed methods research. Thousand Oaks, CA: Sage.

Hale, S. (2007). Community interpreting. Hampshire and New York: Palgrave Macmillan.

Hale, S.; \& Napier, J. (2013). Research methods in interpreting. A practical resource. London \& New York: Bloomsbury.

Hunt Gómez, C. I. (2012). Aplicación de las nuevas tecnologías a la formación de intérpretes en los tribunales de justicia mediante la utilización de material real. (Doctoral thesis, Universidad de Granada, Granada, Spain). Retrieved from: http://hdl.handle.net/10481/26393

Hussein, N. (2011). Legal interpreting in the criminal system: An exploratory study. (Doctoral thesis, De Montfort University, Leicester, United Kingdom). Retrieved from: https://www.dora.dmu.ac.uk/handle/2086/4990 
Isac, D. (2008). Social investigation and community interpreting in the province of Pontevedra. (Unpublished doctoral thesis, Universidad de Vigo, Vigo, Spain).

Keselman, O. (2009). Restricting participation. Unaccompanied children in interpreter-mediated asylum hearings in Sweden. (Doctoral thesis, Linköping University, Linköping, Sweden). Retrieved from: https://www.diva-portal.org/ smash/get/diva2:285469/FULLTEXT01.pdf

Krystallidou, D. (2013). The interpreter's role in medical consultations as perceived and as interactionally negotiated. A study of a Flemish hospital setting, using interview data and video-recorded interactions. (Doctoral thesis, Ghent University, Ghent, Belgium). Retrieved from: http://hdl.handle.net/1854/LU4086069

Lázaro Gutiérrez, R. (2010). La interpretación en los servicios sanitarios en España. Estudio de la asimetría en las consultas médicas con paciente de habla extranjera y la repercusión de la presencia de un intérprete ocasional. (Doctoral thesis, Universidad de Alcalá, Alcalá de Henares, Spain). Retrieved from: http://hdl.handle.net/10017/8067

Martínez-Gómez Gómez, A. (2011). La interpretación en instituciones penitenciarias. La relevancia del componente interpersonal en la calidad de la actuación de intérpretes naturales. (Unpublished doctoral thesis, Universidad de Alicante, Alicante, Spain).

Nevado Llopis, A. (2013). La comunicación intercultural en el ámbito de la salud reproductiva. Propuestas de mejora desde la interpretación en los servicios públicos y la mediación lingüística y cultural. Estudio de caso de un hospital aragonés. (Doctoral thesis, Universidad Jaume I, Castelló de la Plana, Spain). Retrieved from: http://hdl.handle.net/10803/396350

Onos, L. (2014). La interpretación en el ámbito judicial: el caso del rumano en los tribunales de Barcelona. (Doctoral thesis, Universitat Autònoma de Barcelona, Cerdanyola del Vallès, Spain). Retrieved from: http:/www.tdx.cat/handle/ $10803 / 285160$

Ortega Herráez, J. M. (2006). Análisis de la práctica de la interpretación judicial en España: el intérprete frente a su papel profesional. (Doctoral thesis, Universidad de Granada, Granada, Spain). Retrieved from: http://hdl.handle.net/10481/977

Pöchhacker, F. (2004). Introducing interpreting studies. New York: Routledge.

Seale, C. (2003). Quality in qualitative research. In Y. S. Lincoln \& N. K. Denzin (eds.). Turning points in qualitative research. Tying knots in a handkerchief. Walnut Creek, CA: AltaMira Press.

Vargas-Urpi, M. (2011). The interdisciplinary approach in community interpreting research. New voices in translation studies, 7, 47-65. Retrieved from: https://www.iatis.org/images/stories/publications/new-voices/Issue7-2011/ article-vargas-2011.pdf

Vargas-Urpi, M. (2012a). State of the art in community interpreting research. Mapping the main research topics. Babel, 58 (1), 50-72. doi: 10.1075/babel.58.1.04var

Vargas-Urpi, M. (2012b). La interpretació als serveis públics $i$ la mediació intercultural amb el col-lectiu xinès a Catalunya. (Doctoral thesis, Universitat Autònoma de Barcelona, Cerdanyola del Vallès, Spain). Retrieved from: http://hdl.handle.net/10803/96486

Vargas-Urpi, M. (2013). Coping with nonverbal communication in public service interpreting with Chinese immigrants. Journal of intercultural communication research, 42 (4), 340-360. doi: 10.1080/17475759.2013.838985

Wallace, M. (2012). Predictors of successful performance on U.S. Consortium court interpreter certification exams. (Doctoral thesis, Universidad de Alicante, Alicante, Spain). Retrieved from: http://rua.ua.es/dspace/bitstream/10045/ 28364/1/tesis melissawallace.pdf

$\mathrm{Xu}, \mathrm{Z}$. (2015). The career paths of graduates in Chinese interpreting studies: a scientometric exploration. (Unpublished doctoral thesis, Universitat Rovira i Virgili, Tarragona, Spain). 
Annex 1. Doctoral theses on Public Service Interpreting presented in Spain from 2006 to 2015

\begin{tabular}{|c|c|c|c|c|c|}
\hline Author & Year & $\begin{array}{l}\text { Multi- } \\
\text { method? }\end{array}$ & Data collection $^{\text {vii }}$ & $\begin{array}{l}\text { Explicit } \\
\text { triangulation? }\end{array}$ & Length \\
\hline $\begin{array}{l}\text { Abril Martí, } \\
\text { María } \\
\text { Isabel }\end{array}$ & 2006 & No & Documentation & No & 852 \\
\hline $\begin{array}{l}\text { Baixauli- } \\
\text { Olmos, } \\
\text { Lluís }\end{array}$ & 2012 & Yes & $\begin{array}{l}\text { - Collection of } \\
\text { deontological } \\
\text { codes } \\
\text { - } 5 \text { semi-structured } \\
\text { interviews (two } \\
\text { samples of } \\
\text { informants) } \\
\text { - } 72 \text { semi- } \\
\text { structured } \\
\text { questionnaires } \\
\text { (various samples } \\
\text { of informants) } \\
\text { - Direct } \\
\text { observation }\end{array}$ & Yes & 648 \\
\hline $\begin{array}{l}\text { Bodzer, } \\
\text { Anca }\end{array}$ & 2014 & Yes & $\begin{array}{l}\text { - } 210 \\
\text { questionnaires } \\
\text { (various samples } \\
\text { of informants) } \\
\text { - } 6 \text { interviews (two } \\
\text { samples of } \\
\text { informants) } \\
\text { - } 37 \text { records of } \\
\text { direct observation }\end{array}$ & Yes & 697 \\
\hline $\begin{array}{l}\text { Burdeos } \\
\text { Domingo, } \\
\text { Noelia }\end{array}$ & 2015 & Yes & $\begin{array}{l}\text { - } 81 \text { interviews (six } \\
\text { samples of } \\
\text { informants) } \\
\text { - } 110 \\
\text { questionnaires } \\
\text { (two samples of } \\
\text { informants) }\end{array}$ & Yes & 665 \\
\hline $\begin{array}{l}\text { Casamayor } \\
\text { Maspons, } \\
\text { Reynaldo }\end{array}$ & 2013 & $\begin{array}{l}\text { Not } \\
\text { available } \\
\text { (N/A) }\end{array}$ & $\mathrm{N} / \mathrm{A}$ & N/A & 424 \\
\hline $\begin{array}{l}\text { Cayón } \\
\text { Sáez, Luis }\end{array}$ & 2013 & Yes & $\begin{array}{l}\text { - Collection of } \\
\text { documents } \\
\text { - Interviews }\end{array}$ & $\mathrm{N} / \mathrm{A}$ & 229 \\
\hline $\begin{array}{l}\text { Foulquié } \\
\text { Rubio, Ana }\end{array}$ & 2015 & No & $\begin{array}{l}\text { - } 218 \\
\text { questionnaires ( } 75 \\
\text { in the pilot study, } \\
143 \text { in the final } \\
\text { study) }\end{array}$ & No & 566 \\
\hline $\begin{array}{l}\text { Hunt } \\
\text { Gómez, } \\
\text { Coral Ivy }\end{array}$ & 2012 & Yes & $\begin{array}{l}\text { - } 127 \\
\text { questionnaires } \\
-2 \text { focus groups }\end{array}$ & No & 428 \\
\hline Isac, Dana & 2008 & Yes & $\begin{array}{l}\text { - Questionnaires } \\
\text { - Direct } \\
\text { observation }\end{array}$ & N/A & N/A \\
\hline $\begin{array}{l}\text { Lázaro } \\
\text { Gutiérrez, } \\
\text { Raquel }\end{array}$ & 2010 & No & $\begin{array}{l}\text { - Recordings of } 75 \\
\text { interactions }\end{array}$ & No & 475 \\
\hline $\begin{array}{l}\text { Martínez- } \\
\text { Gómez } \\
\text { Gómez, } \\
\text { Aída }\end{array}$ & 2011 & Yes & $\begin{array}{l}\text { - Questionnaires } \\
\text { - Recordings of } 19 \\
\text { meetings }\end{array}$ & No & 738 \\
\hline $\begin{array}{l}\text { Nevado } \\
\text { Llopis, } \\
\text { Almudena }\end{array}$ & 2013 & Yes & $\begin{array}{l}\text { - Collection of } \\
\text { documents } \\
\text { - } 49 \text { semi- } \\
\text { structured } \\
\text { interviews } \\
\text { - Non-participant }\end{array}$ & Yes & 711 \\
\hline
\end{tabular}

Translation \& Interpreting Vol 9 No 1 (2017) 


\begin{tabular}{|c|c|c|c|c|c|}
\hline & & & $\begin{array}{l}\text { observation of } 14 \\
\text { medical } \\
\text { consultations } \\
\text { - } 3 \text { Focus groups }\end{array}$ & & \\
\hline $\begin{array}{l}\text { Onos, } \\
\text { Liudmila }\end{array}$ & 2014 & Yes & $\begin{array}{l}\text { - } 14 \text { semi- } \\
\text { structured } \\
\text { interviews ( } 3 \\
\text { samples of } \\
\text { informants) } \\
\text { - Direct } \\
\text { observation of } 56 \\
\text { court sessions }\end{array}$ & Yes & 544 \\
\hline $\begin{array}{l}\text { Ortega } \\
\text { Herráez, } \\
\text { Juan } \\
\text { Miguel }\end{array}$ & 2006 & Yes & $\begin{array}{l}\text { - Collection of } \\
\text { documents } \\
\text { - } 83 \text { questionnaires }\end{array}$ & No & 908 \\
\hline $\begin{array}{l}\text { Vargas- } \\
\text { Urpi, Mireia }\end{array}$ & 2012 & Yes & $\begin{array}{l}\text {-30 semi- } \\
\text { structured } \\
\text { interviews } \\
-76 \text { questionnaires }\end{array}$ & Yes & 678 \\
\hline $\begin{array}{l}\text { Wallace, } \\
\text { Melissa }\end{array}$ & 2012 & Yes & $\begin{array}{l}\text { - } 84 \text { questionnaires } \\
\text { - Collection of } \\
\text { documents ( } 6,000 \\
\text { exam scores) }\end{array}$ & No & 352 \\
\hline
\end{tabular}

Annex 2. Doctoral theses on Public Service Interpreting presented in other European countries from 2006 to 2015 according to BITRA on $10^{\text {th }}$ March 2017

\begin{tabular}{|c|c|c|c|c|c|}
\hline Author & Year & $\begin{array}{l}\text { Multi- } \\
\text { method } \\
?\end{array}$ & Data collection & $\begin{array}{l}\text { Explicit } \\
\text { triangulation? }\end{array}$ & Length \\
\hline $\begin{array}{l}\text { Amato, } \\
\text { Amalia }\end{array}$ & 2007 & No & $\begin{array}{l}\text { Recordings of } \\
\text { naturally-occurring } \\
\text { interactions }\end{array}$ & No & 169 \\
\hline Davitti, Elena & 2012 & No & $\begin{array}{l}\text { Recordings of } \\
\text { naturally-occurring } \\
\text { interactions }\end{array}$ & No & 323 \\
\hline $\begin{array}{l}\text { Fowler, } \\
\text { Yvonne }\end{array}$ & 2012 & Yes & $\begin{array}{l}\text { - } 11 \text { audio } \\
\text { recordings } \\
\text { - } 10 \text { video } \\
\text { recordings } \\
\text { - } 27 \text { semi- } \\
\text { structured } \\
\text { interviews } \\
\text { - ethnographic } \\
\text { observation }\end{array}$ & Yes & 430 \\
\hline $\begin{array}{l}\text { Gallez, } \\
\text { Emmanuelle }\end{array}$ & 2014 & No & $\begin{array}{l}\text { Transcripts of } \\
\text { three successive } \\
\text { speeches }\end{array}$ & No & 441 \\
\hline $\begin{array}{l}\text { Hussein, } \\
\text { Nadia. M. A. }\end{array}$ & 2011 & Yes & $\begin{array}{l}\text { - Questionnaires } \\
\text { - Semi-structured } \\
\text { interviews } \\
\text { - Participant } \\
\text { observation }\end{array}$ & No & 316 \\
\hline $\begin{array}{l}\text { lacono, } \\
\text { Eleonora }\end{array}$ & 2013 & No & $\begin{array}{l}\text { Recordings of } \\
\text { naturally-occurring } \\
\text { interactions }\end{array}$ & No & 523 \\
\hline Jiang Lihua & 2008 & No & $\begin{array}{l}\text { Theoretically- } \\
\text { oriented research }\end{array}$ & No & 235 \\
\hline $\begin{array}{l}\text { Kaczmarek, } \\
\text { Lukasz }\end{array}$ & 2010 & No & $\begin{array}{l}\text { Interviews to } \\
\text { various groups of } \\
\text { informants }\end{array}$ & No & 301 \\
\hline $\begin{array}{l}\text { Keselman, } \\
\text { Olga }\end{array}$ & 2009 & Yes & $\begin{array}{l}\text { - Recordings of } \\
\text { authentic asylum } \\
\text { hearings } \\
\text { - Audiotaped } \\
\text { interviews with }\end{array}$ & No & 59 \\
\hline
\end{tabular}




\begin{tabular}{|c|c|c|c|c|c|}
\hline & & & $\begin{array}{l}\text { various groups of } \\
\text { informants } \\
\text { - Document } \\
\text { analysis }\end{array}$ & & \\
\hline $\begin{array}{l}\text { Krystallidou, } \\
\text { Demi K. }\end{array}$ & 2013 & Yes & $\begin{array}{l}\text { - } 9 \text { video-recorded } \\
\text { mediated } \\
\text { consultations } \\
\text { - } 25 \text { audio } \\
\text { recorded semi- } \\
\text { structured } \\
\text { interviews }\end{array}$ & N/A & 303 \\
\hline $\begin{array}{l}\text { Mullamaa, } \\
\text { Kristina }\end{array}$ & 2006 & $\mathrm{~N} / \mathrm{A}$ & $\mathrm{N} / \mathrm{A}$ & $\mathrm{N} / \mathrm{A}$ & 236 \\
\hline $\begin{array}{l}\text { Niemants, } \\
\text { Natacha S. } \\
\text { A. }\end{array}$ & 2012 & No & $\begin{array}{l}\text { - Recordings of } \\
\text { simulated } \\
\text { interactions }\end{array}$ & No & 353 \\
\hline $\begin{array}{l}\text { Zimányi, } \\
\text { Krisztina }\end{array}$ & 2010 & No & $\begin{array}{l}\text { - Recordings of } \\
\text { interviews }\end{array}$ & No & 337 \\
\hline
\end{tabular}

${ }^{\mathrm{i}}$ For the purpose of the present article, dissertations on sign language interpreting have not been considered.

${ }^{\mathrm{ii}}$ The Comunica network comprises different research groups in Spain devoted to the study of PSI. (URL: http://red-comunica.blogspot.com.es/). Dr. Ortega Herráez is currently coordinating the construction of the aforementioned catalogue.

iii "[C]oncepción y práctica de conocimiento que busca comprender los fenómenos sociales desde la perspectiva de sus miembros (entendidos como "actores", "agentes" o "sujetos sociales" (Guber, 2001, p.12). Translated from Spanish by the author of the article.

${ }^{\mathrm{iv}}$ Bodzer (2014) describes collecting 210 questionnaires distributed among various samples (a specific questionnaire was designed for each sample): 120 interpreters, 60 lawyers, 9 psychologist, 13 social workers, 2 managers of shelter houses, and 6 victims.

${ }^{v}$ Wallace (2012) used the certification exam administered by the Consortium for Language Access in the Courts (USA). For more information, see:

http://www.ncsc.org/Education-and-Careers/State-Interpreter-Certification.aspx (last access $9^{\text {th }}$ March 2017).

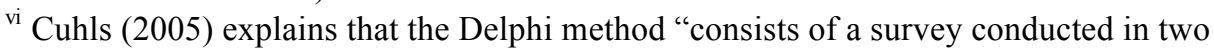
or more rounds and provides the participants in the second round with the results of the first so that they can alter the original assessments if they want to - or stick to their previous opinion. Nobody 'loses face' because the survey is done anonymously using a questionnaire (...)".

vii Numerical information is provided whenever it was available (in some cases, only the abstracts of the theses were accessible). 